\title{
Aureitalea marina gen. nov., sp. nov., a member of the family Flavobacteriaceae, isolated from seawater
}

\author{
Correspondence \\ Sanghwa Park \\ psh214@hotmail.com
}

\author{
Sanghwa Park, ${ }^{1}$ Susumu Yoshizawa, ${ }^{2}$ Kentaro Inomata, ${ }^{2}$ \\ Kazuhiro Kogure ${ }^{2}$ and Akira Yokota ${ }^{1}$ \\ ${ }^{1}$ Institute of Molecular and Cellular Biosciences, The University of Tokyo, 1-1-1 Yayoi, \\ Bunkyo-Ku, Tokyo 113-0032, Japan
${ }^{2}$ Atmosphere and Ocean Research Institute, The University of Tokyo, 5-1-5 Kashiwanoha, Kashiwa, Chiba 277-8564, Japan

\begin{abstract}
An irregular rod-shaped, non-gliding, yellow-pigmented bacterium was isolated from seawater from the western North Pacific Ocean near Japan. The strain, designated $S 1-66^{\top}$, was Gram-negative, obligately aerobic, heterotrophic and oxidase-positive. Growth occurred in the presence of $1-4 \% \mathrm{NaCl}$, with optimum growth at $2 \% \mathrm{NaCl}$. The strain grew at $15-30{ }^{\circ} \mathrm{C}$, with optimum growth at $20-25{ }^{\circ} \mathrm{C}$. The $\mathrm{G}+\mathrm{C}$ content of genomic DNA was $48.1 \mathrm{~mol} \%$ (HPLC). The predominant isoprenoid quinone was MK- 6 and the major cellular fatty acids were iso- $\mathrm{C}_{15: 0}$ $(26.4 \%)$, iso- $\mathrm{C}_{15: 1}(20.3 \%)$ and iso- $\mathrm{C}_{17: 0} 3-\mathrm{OH}$ (14.2\%). Phylogenetic trees generated by using $16 \mathrm{~S}$ rRNA gene sequences revealed that strain $\mathrm{S} 1-66^{\top}$ belongs to the family Flavobacteriaceae and showed $94.2 \%$ sequence similarity to the most closely related type strain, Ulvibacter antarcticus IMCC $3101^{\top}$. On the basis of phenotypic and phylogenetic features, $\mathrm{S} 1-66^{\top}$ is classified in a novel genus and species within the family Flavobacteriaceae, for which the name Aureitalea marina gen. nov., sp. nov. is proposed. The type strain of Aureitalea marina is $\mathrm{S} 1-66^{\top}\left(=\right.$ NBRC $107741^{\top}=$ KCTC $\left.23434^{\top}\right)$.
\end{abstract}

The family Flavobacteriaceae, belonging to the phylum Bacteroidetes (the Cytophaga-Flavobacterium-Bacteroides group), was proposed by Reichenbach (1992) and its description was subsequently emended by Bernardet et al. (1996, 2002). Currently the family Flavobacteriaceae comprises more than 90 genera (http://www.bacterio.cict. fr). Most members of the family have been isolated from diverse marine environments, including the deep sea (Romanenko et al., 2007), sediment (Khan et al., 2008), Antarctic water (Macián et al., 2002) and marine plants and animals (Nedashkovskaya et al., 2005; Bae et al., 2007).

An aerobic, yellow-pigmented bacterium, strain $\mathrm{S} 1-66^{\mathrm{T}}$, was isolated from seawater samples from the western North Pacific Ocean $\left(30^{\circ} 11^{\prime} \mathrm{N} 145^{\circ} 05^{\prime} \mathrm{E}\right.$; depth, $\left.100 \mathrm{~m}\right)$, and found to belong to the family Flavobacteriaceae. A polyphasic taxonomic analysis of this isolate demonstrated that it represents a novel genus and species in the family.

Strain S1-66 ${ }^{\mathrm{T}}$ was isolated from seawater samples collected from the R/V Mirai [Japan Agency for Marine-Earth

Abbreviations: ML, maximum-likelihood; NJ, neighbour-joining.

The GenBank/EMBL/DDBJ accession number for the $16 \mathrm{~S}$ rRNA gene sequence of strain $\mathrm{S} 1-66^{\top}$ is $\mathrm{AB} 602429$.

A supplementary figure is available with the online version of this paper.
Science and Technology (JAMSTEC)] on 9 February 2010 (cruise MR10-01). An aliquot of seawater $(200 \mu \mathrm{l})$ was inoculated onto 1/10-strength ZoBell agar medium $(0.5 \mathrm{~g}$ peptone, $0.1 \mathrm{~g}$ yeast extract, $15 \mathrm{~g}$ agar in $1180 \%$ aged natural seawater) and incubated at $15{ }^{\circ} \mathrm{C}$ for 30 days. The isolated strain was maintained on 1/2-strength marine agar 2216 (1/2 MA) (Difco) containing $2 \% \mathrm{NaCl}$ at $20{ }^{\circ} \mathrm{C}$. Ranges of temperature $\left(5,10,15,20,25,30,37\right.$ and $\left.45^{\circ} \mathrm{C}\right)$ and $\mathrm{pH}(\mathrm{pH} 5-10)$ for growth were determined by incubating the isolate on $1 / 2 \mathrm{MA}$ containing $2 \% \mathrm{NaCl}$. The $\mathrm{NaCl}$ concentration for growth was determined on $1 / 2$ MA $\left(1^{-1}: 15 \mathrm{~g}\right.$ agar, $4.4 \mathrm{~g} \mathrm{MgCl}_{2}, 2.5 \mathrm{~g}$ peptone, $1.62 \mathrm{~g}$ $\mathrm{Na}_{2} \mathrm{SO}_{3}, 0.9 \mathrm{~g} \mathrm{CaCl}_{2}, 0.5 \mathrm{~g}$ yeast extract, $0.27 \mathrm{~g} \mathrm{KCl}, 0.8 \mathrm{~g}$ $\mathrm{NaHCO}_{3}, 0.5 \mathrm{~g}$ ferric citrate, $0.04 \mathrm{~g} \mathrm{KBr}, 0.015 \mathrm{~g} \mathrm{SrCl}_{2}$, $0.01 \mathrm{~g} \mathrm{H}_{3} \mathrm{BO}_{3}, 4 \mathrm{mg} \mathrm{Na} \mathrm{NPO}_{4}, 2 \mathrm{mg} \mathrm{Na} \mathrm{NiO}_{3}, 1.2 \mathrm{mg}$ $\left.\mathrm{NaF}, 0.8 \mathrm{mg} \mathrm{NH}_{4} \mathrm{NO}_{3}\right)$ containing $0-15 \%(\mathrm{w} / \mathrm{v}) \mathrm{NaCl}$. Gram-staining was performed as described by Murray et al. (1994). Cell morphology and motility were observed using light microscopy (BX60; Olympus). Growth under anaerobic conditions was determined after incubation for 4 weeks in an AnaeroPack (Mitsubishi Gas Chemical Co.) on $1 / 2 \mathrm{MA}$ containing $2 \% \mathrm{NaCl}$. Catalase activity was determined by bubble formation in a $3 \% \mathrm{H}_{2} \mathrm{O}_{2}$ solution. Oxidase activity was determined using cytochrome oxidase test paper (Nissui Pharmaceutical Co.). 
API 20E, API 20NE, API 50CH and API ZYM strips (bioMérieux) were used to determine physiological and biochemical characteristics. Suspension media for the API test strips were supplemented with $2 \%(\mathrm{w} / \mathrm{v}) \mathrm{NaCl}$ (final concentration). API 20E, API 20NE, API $50 \mathrm{CH}$ and API ZYM test strips were read after incubation for 5 and 2 days at $20{ }^{\circ} \mathrm{C}$. Determination of the respiratory quinone was carried out as described previously (Xie \& Yokota, 2003). A culture grown on $1 / 2 \mathrm{MA}$ containing $2 \% \mathrm{NaCl}$ for 3 weeks at $20{ }^{\circ} \mathrm{C}$ was used for the analysis of fatty acid methyl esters. Fatty acid methyl esters were extracted and prepared according to standard protocols provided by the MIDI/ Hewlett Packard Microbial Identification system (Sasser, 1990) and then analysed by using the Sherlock 4 software. Polar lipids were extracted according to the procedures described by Minnikin et al. (1984) and identified by twodimensional TLC followed by spraying with appropriate detection reagents (Minnikin et al., 1984; Komagata \& Suzuki, 1987). Phospholipids were detected with the Zinzadze reagent (Dittmer \& Lester, 1964). Whole lipid profiles were detected by spraying with molybdatophosphoric acid (10 g molybdatophosphoric acid hydrate in $100 \mathrm{ml}$ ethanol) followed by heating at $120-160{ }^{\circ} \mathrm{C}$ (Worliczek et al., 2007). DNA was prepared according to the method of Marmur (1961) from cells grown on 1/2 MA containing $2 \% \mathrm{NaCl}$ and the DNA base composition was determined by using the HPLC method of Mesbah et al. (1989). A fragment of approximately $1450 \mathrm{bp}$ from the $16 \mathrm{~S}$ rRNA gene was amplified from the extracted DNA by using bacterial universal primers $27 \mathrm{~F}$ and $1492 \mathrm{R}$ specific to the 16 S rRNA gene (Lane, 1991; Weisburg et al., 1991). To ascertain the phylogenetic position of the novel isolate, the $16 \mathrm{~S}$ rRNA gene sequence of strain $\mathrm{S} 1-66^{\mathrm{T}}$ was compared with sequences obtained from GenBank (National Center for Biotechnology Information; http://www.ncbi.nlm.nih. gov). Multiple alignments of sequences were performed using CLUSTAL_X (version 1.83) (Thompson et al., 1997). Alignment gaps and ambiguous bases were not taken into consideration when 1327 bases of the $16 \mathrm{~S}$ rRNA gene were compared. Aligned sequences were analysed using MEGA 4 (Tamura et al., 2007). Evolutionary distances [distance options according to Kimura's two-parameter model (Kimura, 1983)] and clustering with the neighbour-joining (NJ; Saitou \& Nei, 1987) and maximum-likelihood (ML; Felsenstein, 1981) methods using PhyML program version 2.4.4 (Guindon \& Gascuel, 2003) were determined by using bootstrap values based on 1000 replications (Felsenstein, 1985).

An almost-complete 16S rRNA gene sequence for strain S1$66^{\mathrm{T}}$ was determined and a FASTA search in GenBank showed that the strain belongs to the family Flavobacteriaceae. Species with validly published names exhibited $<95 \%$ sequence similarity to the determined sequence. Strain S1$66^{\mathrm{T}}$ displayed the highest 16S rRNA gene sequence similarity to Ulvibacter antarcticus IMCC $3101^{\mathrm{T}}$ (94.2\% similarity), Ulvibacter litoralis KMM $3912^{\mathrm{T}}$ (93.9\%), Marixanthomonas ophiurae $\mathrm{KMM} 3046^{\mathrm{T}}$ (92.6\%), Vitellibacter vladivostokensis KMM $3516^{\mathrm{T}}(90.1 \%)$, Aequorivita antarctica SW49 ${ }^{\mathrm{T}}$ $(89.7 \%)$ and Croceibacter atlanticus HTCC2559 ${ }^{\mathrm{T}}$ (87.8\%). Phylogenetic trees obtained by the NJ (Fig. 1) and ML methods revealed a clear affiliation of the novel isolate S1$66^{\mathrm{T}}$ to the cluster of $U$. antarcticus IMCC $3101^{\mathrm{T}}$, U. litoralis KMM $3912^{\mathrm{T}}$, M. ophiurae KMM $3046^{\mathrm{T}}$, V. vladivostokensis KMM $3516^{\mathrm{T}}$, A. antarctica $\mathrm{SW} 49^{\mathrm{T}}$ and $C$. atlanticus HTCC $2559^{\mathrm{T}}$. Strain S1-66 ${ }^{\mathrm{T}}$ formed a cluster with $U$. antarcticus $\mathrm{IMCC} 3101^{\mathrm{T}}$ and $U$. litoralis $\mathrm{KMM} 3912^{\mathrm{T}}$ with bootstrap confidence values of $87 \%(\mathrm{NJ})$ and $76 \%(\mathrm{ML})$.

Cultural, physiological and biochemical characteristics of S1-66 ${ }^{\mathrm{T}}$ were compared with those of members of the related genera Ulvibacter, Marixanthomonas, Vitellibacter, Aequorivita and Croceibacter.

Cells of strain $\mathrm{S} 1-66^{\mathrm{T}}$ grown on 1/2 MA containing $2 \%$ $\mathrm{NaCl}$ at $20{ }^{\circ} \mathrm{C}$ for 3 weeks were irregular rod-shaped, yellow-pigmented, approximately $0.5-1 \mu \mathrm{m}$ wide and $0.5-$ $6 \mu \mathrm{m}$ long. Spores were not observed microscopically. The yellow pigment that accumulated in the cells was extracted with acetone after freeze-drying treatment of the cells and analysed using a Beckman DU 530 UV-Vis spectrophotometer. The pigment showed a UV-visible spectrum with absorption maxima at 343, 452 and $487 \mathrm{~nm}$. Flexirubintype pigments were not detected when investigated by using the bathochromic shift test with a $20 \%(\mathrm{w} / \mathrm{v}) \mathrm{KOH}$ solution (Fautz \& Reichenbach, 1980; Bernardet et al., 2002). No growth was observed under anaerobic conditions in $1 / 2 \mathrm{MA}$ containing $2 \% \mathrm{NaCl}$. Growth occurred only under aerobic conditions at $15-30{ }^{\circ} \mathrm{C}$. The optimal temperature and $\mathrm{pH}$ were $20-25^{\circ} \mathrm{C}$ and $\mathrm{pH} 7-8$. Oxidase

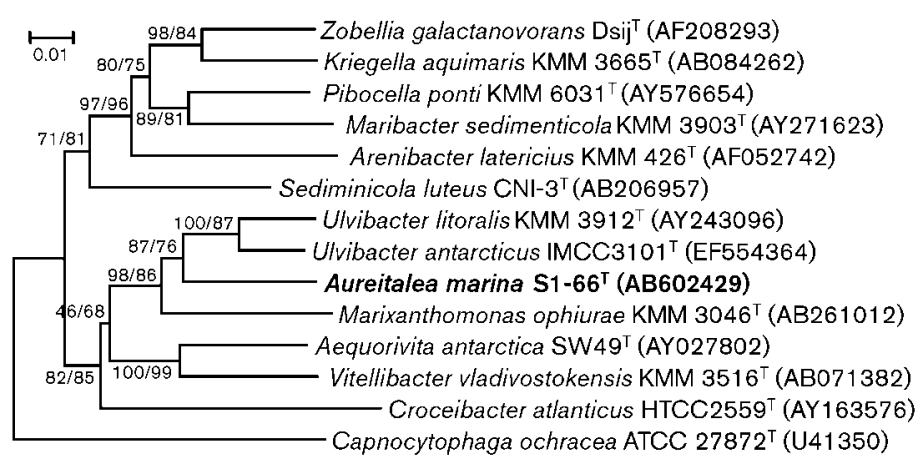

Fig. 1. NJ phylogenetic tree based on $16 \mathrm{~S}$ rRNA gene sequences showing the position of strain $\mathrm{S} 1-66^{\top}$ among currently known and related species of the family Flavobacteriaceae. Numbers at nodes are bootstrap percentages derived from 1000 replications (NJ/ML). The sequence of Capnocytophaga ochracea ATCC $27872^{\top}$ was used as outgroup. Bar, 0.01 substitutions per nucleotide position. 
Table 1. Differential characteristics of strain $\mathrm{S} 1-66^{\top}$ and members of related genera in the family Flavobacteriaceae

Taxa: 1, strain S1-66 ; 2, Ulvibacter (data from Nedashkovskaya et al., 2004; Choi et al., 2007); 3, Marixanthomonas (Romanenko et al., 2007); 4, Vitellibacter (Nedashkovskaya et al., 2003; Kim et al, 2010); 5, Aequorivita (Bowman \& Nichols, 2002; Park et al., 2009); 6, Croceibacter (Cho \& Giovannoni, 2003). +, Positive; v, variable; -, negative; ND, no data available.

\begin{tabular}{|c|c|c|c|c|c|c|}
\hline Characteristic & 1 & 2 & 3 & 4 & 5 & 6 \\
\hline Flexirubin-type pigment & - & + & - & + & - & - \\
\hline Gliding motility & - & $\mathrm{v}$ & - & - & ND & - \\
\hline Cell length $(\mu \mathrm{m})$ & $0.5-6$ & $0.5-7.3$ & $2.2-2.8$ & $3-10$ & $0.5-20$ & $1.2-3.1$ \\
\hline \multicolumn{7}{|l|}{ Temperature for growth $\left({ }^{\circ} \mathrm{C}\right)$} \\
\hline Range & $15-30$ & $3-36$ & $5-32$ & $4-43$ & -2 to 40 & $10-28$ \\
\hline Optimum & $20-25$ & $21-25$ & $25-28$ & $28-35$ & $20-25$ & $0.5-15$ \\
\hline $\mathrm{NaCl}$ concentration for growth $(\%, \mathrm{w} / \mathrm{v})$ & $1-4$ & $1-6$ & $1-12$ & $1-6$ & $1-8$ & $0.5-15$ \\
\hline Catalase & - & + & + & $\mathrm{V}$ & + & + \\
\hline Oxidase & + & + & + & + & - & - \\
\hline Nitrate reduction & + & $\mathrm{V}$ & - & - & - & - \\
\hline Acid production from glucose & + & - & - & - & - & - \\
\hline \multicolumn{7}{|l|}{ Hydrolysis of: } \\
\hline Starch & + & $\mathrm{V}$ & - & - & $\mathrm{V}$ & + \\
\hline Gelatin & + & + & + & + & + & + \\
\hline Urea & - & - & + & - & $\mathrm{V}$ & $\mathrm{ND}$ \\
\hline Major fatty acids* & $\begin{array}{l}\mathrm{i}-\mathrm{C}_{15: 0}, \mathrm{i}-\mathrm{C}_{15: 1}, \\
\mathrm{i}-\mathrm{C}_{17: 0} 3-\mathrm{OH}, \\
\mathrm{i}-\mathrm{C}_{15: 0} 2-\mathrm{OH}\end{array}$ & $\begin{array}{c}\mathrm{i}-\mathrm{C}_{17: 0} 3-\mathrm{OH}, \mathrm{i}-\mathrm{C}_{15: 0} \\
\mathrm{i}-\mathrm{C}_{16: 0}, \mathrm{i}-\mathrm{C}_{16: 0} 3-\mathrm{OH}, \\
\mathrm{i} \mathrm{C}_{15: 1}\end{array}$ & $\begin{array}{c}\mathrm{i}-\mathrm{C}_{16: 0} 3-\mathrm{OH}, \mathrm{i}-\mathrm{C}_{17: 0} \\
3-\mathrm{OH}, \text { ai- } \mathrm{C}_{17: 0} 3-\mathrm{OH} \\
\mathrm{C}_{16: 0}, \mathrm{C}_{18: 0}\end{array}$ & $\begin{array}{c}\mathrm{i}-\mathrm{C}_{15: 0}, \mathrm{i}-\mathrm{C}_{17: 0} \\
3-\mathrm{OH}\end{array}$ & $\begin{array}{l}\mathrm{i}-\mathrm{C}_{15: 1} \omega 10 c, \text { ai- }-\mathrm{C}_{15: 1} \omega 10 c \\
\text { ai- } \mathrm{C}_{15: 0}, \mathrm{i}-\mathrm{C}_{15: 0}, \mathrm{i}-\mathrm{C}_{16: 1} \omega 6 c \\
\quad \mathrm{i}-\mathrm{C}_{17: 1} \omega 5 c, \text { ai- }-\mathrm{C}_{17: 1} \omega 7 c\end{array}$ & $\begin{array}{l}\mathrm{i}-\mathrm{C}_{17: 0} 3-\mathrm{OH}, \\
\mathrm{i}-\mathrm{C}_{15: 0}, \mathrm{i}-\mathrm{C}_{15: 1}, \\
\quad \mathrm{i}-\mathrm{C}_{17: 1} \omega 9 \mathrm{c}\end{array}$ \\
\hline \multicolumn{7}{|l|}{ Presence of: $\dagger$} \\
\hline ai- $\mathrm{C}_{15: 0}$ and $\mathrm{i}-\mathrm{C}_{15: 1}$ & + & + & - & + & $+1-$ & + \\
\hline $\mathrm{i}-\mathrm{C}_{16: 1}$ and $\mathrm{i}-\mathrm{C}_{17: 1} \omega 9 c$ & - & + & - & $-1+$ & - & + \\
\hline Polar lipids $\ddagger$ & PG, DPG, GLx & ND & SL, PE, lysoPE, APL & ND & ND & ND \\
\hline DNA G $+\mathrm{C}$ content $(\mathrm{mol} \%)$ & 48.1 & $36.7-38.0$ & 37.3 & $41.3-48.7$ & $33.5-39.1$ & 34.8 \\
\hline
\end{tabular}

*ai, Anteiso-branched; i, iso-branched.

$\dagger$ When two results are given, they indicate the presence of the first/second fatty acid listed.

‡DPG, Diphosphatidylglycerol; PE, phosphatidylethanolamine; lysoPE, lysophosphatidylethanolamine; SL, sphingolipid; APL, aminophospholipid; GLx, unknown glycolipid. 
tested positive but catalase tested negative. The DNA G $+\mathrm{C}$ content of strain $\mathrm{S} 1-66^{\mathrm{T}}$ was $48.1 \mathrm{~mol} \%$, which distinguished strain $\mathrm{S} 1-66^{\mathrm{T}}$ from the related genera Ulvibacter, Marixanthomonas, Aequorivita and Croceibacter. Strain S1$66^{\mathrm{T}}$ required $\mathrm{NaCl}$ for growth and grew in $1-4 \% \mathrm{NaCl}$ (Table 1). The major cellular fatty acids were iso- $\mathrm{C}_{15: 0}$ $(26.4 \%)$, iso- $\mathrm{C}_{15: 1}(20.3 \%)$, iso- $\mathrm{C}_{17: 0} 3-\mathrm{OH}(14.2 \%)$, iso$\mathrm{C}_{15: 0} 2-\mathrm{OH}(7.8 \%)$ and iso- $\mathrm{C}_{16: 0}(5.2 \%)$ (Table 2).

The polar lipid composition of strain $\mathrm{S} 1-66^{\mathrm{T}}$ contained three major polar lipids, phosphatidylglycerol, diphosphatidylglycerol and an unidentified glycolipid (Fig. S1, available in IJSEM Online), while members of Marixanthomonas contained sphingolipid, phosphatidylethanolamine, lysophosphatidylethanolamine, aminophospholipid and an unknown lipid. Strain $S 1-66^{\mathrm{T}}$ showed no catalase activity, gliding motility or flexirubin-type pigments, while members of the most closely related genus Ulvibacter tested positive for these characteristics. DNA G $+\mathrm{C}$ contents, acid production from glucose, nitrate reduction and the absence of iso$\mathrm{C}_{16: 1}$ and iso- $\mathrm{C}_{17: 1} \omega 9 c$ fatty acids distinguished strain S1$66^{\mathrm{T}}$ from members of the genus Ulvibacter.

Phenotypic differences among strain $\mathrm{S} 1-66^{\mathrm{T}}$ and related species are shown in Tables 1 and 2. The data presented showed that strain $S 1-66^{\mathrm{T}}$ is sufficiently different from related genera to justify its assignment to a novel genus and species, Aureitalea marina gen. nov., sp. nov., in the family Flavobacteriaceae.

\section{Description of Aureitalea gen. nov.}

Aureitalea (Au.re.i.ta'le.a. L. adj. aureus golden; L. fem. n. talea a rod; N.L. fem. n. Aureitalea golden rod).

Cells are yellow-pigmented. Flexirubin-type pigments are not produced. Irregular rod-shaped cells. Do not form endospores. Gram-stain-negative and obligately aerobic. The major respiratory quinone is MK-6. Predominant cellular fatty acids are iso- $C_{15: 0}$, iso- $C_{15: 1}$ and iso- $C_{17: 0}$ 3-OH. The type species is Aureitalea marina.

\section{Description of Aureitalea marina sp. nov.}

Aureitalea marina (ma.ri'na. L. fem. adj. marina of or belonging to the sea, marine).

Exhibits the following properties in addition to those given in the genus description. Cells are $0.4-0.6 \mu \mathrm{m}$ wide and $0.5-6 \mu \mathrm{m}$ long. Non-gliding motility is observed. Temperature range for growth is $15-30{ }^{\circ} \mathrm{C}$; optimal temperature $20-25{ }^{\circ} \mathrm{C}$. No growth occurs above $30{ }^{\circ} \mathrm{C}$. Grows at $\mathrm{pH}$ 6.0-9.0. $\mathrm{NaCl}$ is required for growth and can be tolerated at up to $4 \%(\mathrm{w} / \mathrm{v})$. Catalase-negative but oxidase-positive. Production of acetoin and reduction of nitrate to $\mathrm{N}_{2}$ are observed. Gelatin and starch are hydrolysed but agar is not hydrolysed. Alkaline phosphatase, leucine arylamidase, valine arylamidase, cystine arylamidase, trypsin, $\alpha$-chymotrypsin, acid phosphatase, naphthol-AS-BI-phosphohydrolase and $\beta$-glucosidase
Table 2. Cellular fatty acid compositions of strain $\mathrm{S} 1-66^{\top}$ and type strains of related species in the family Flavobacteriaceae

Strains: 1, strain S1-66 ${ }^{\mathrm{T}} ; 2$, Ulvibacter antarcticus $\mathrm{IMCC} 101^{\mathrm{T}}$ (data from Choi et al., 2007); 3, Ulvibacter litoralis $\mathrm{KMM} 3912^{\mathrm{T}}$ (Nedashkovskaya et al., 2004); 4, Marixanthomonas ophiurae KMM $3046^{\mathrm{T}}$ (Romanenko et al., 2007); 5, Vitellibacter vladivostokensis $\mathrm{KMM}$ $3516^{\mathrm{T}}$ (Kim et al., 2010); 6, Aequorivita antarctica SW49 ${ }^{\mathrm{T}}$ (Bowman \& Nichols, 2002); 7, Croceibacter atlanticus HTCC2559 ${ }^{\mathrm{T}}$ (Cho \& Giovannoni, 2003). Values are percentages of total fatty acids; -, not detected/not reported.

\begin{tabular}{|c|c|c|c|c|c|c|c|}
\hline Fatty acid & 1 & 2 & 3 & 4 & 5 & 6 & 7 \\
\hline $\mathrm{C}_{15: 0}$ & 4.6 & 1.2 & 3.9 & 2.4 & 4.3 & - & 3.9 \\
\hline$C_{16: 0}$ & 0.9 & - & - & 6.9 & 1.7 & 1.9 & 0.6 \\
\hline $\mathrm{C}_{18: 0}$ & - & - & - & 5.2 & - & - & 0.2 \\
\hline iso- $\mathrm{C}_{15: 0}$ & 26.4 & 15.3 & 21.3 & 2.9 & 32.4 & 7.6 & 13.3 \\
\hline anteiso- $C_{15: 0}$ & 3.8 & 1.3 & 2.3 & - & 3.8 & 15.7 & 1.6 \\
\hline iso- $\mathrm{C}_{15: 1}$ & 20.3 & 3.9 & 12.5 & - & 2.4 & - & 9.2 \\
\hline iso- $\mathrm{C}_{15: 1} \omega 10 c$ & - & - & - & - & - & 9.5 & - \\
\hline anteiso- $\mathrm{C}_{15: 1} \omega 10 c$ & - & - & - & - & - & 16.0 & - \\
\hline iso- $\mathrm{C}_{16: 0}$ & 5.3 & 11.0 & 2.8 & 1.8 & 2.7 & 1.4 & 1.5 \\
\hline iso- $\mathrm{C}_{16: 1}$ & - & 5.4 & 4.2 & - & - & - & 1.7 \\
\hline iso- $\mathrm{C}_{15: 0} 3-\mathrm{OH}$ & 3.3 & 4.1 & 3.3 & - & 3.5 & 5.4 & 4.3 \\
\hline iso- $\mathrm{C}_{16: 0} 3-\mathrm{OH}$ & 2.9 & 9.2 & 8.7 & 41.2 & 1.4 & 9.2 & 4.4 \\
\hline iso- $\mathrm{C}_{17: 0} 3-\mathrm{OH}$ & 14.2 & 19.4 & 17.2 & 16.4 & 23.2 & 2.0 & 28.0 \\
\hline anteiso- $\mathrm{C}_{17: 0} 3-\mathrm{OH}$ & - & - & - & 5.1 & - & 2.9 & - \\
\hline iso- $\mathrm{C}_{17: 1} \omega 9 c$ & - & 2.2 & 3.7 & - & 9.0 & - & 9.4 \\
\hline Summed feature $3^{*}$ & $7.8 \dagger$ & 5.9 & 5.7 & - & 6.9 & - & 5.1 \\
\hline
\end{tabular}

${ }^{*}$ Summed features are groups of two or three fatty acids that cannot be separated by GLC with the MIDI System. Summed feature 3 comprised $\mathrm{C}_{16: 1} \omega 7 c$ and/or iso- $\mathrm{C}_{15: 0} 2-\mathrm{OH}$.

$\dagger$ Identified as iso- $\mathrm{C}_{15: 0} 2-\mathrm{OH}$.

activities are present, but esterase (C4), esterase lipase (C8), lipase (C14), $N$-acetyl- $\beta$-glucosaminidase, $\alpha$-galactosidase, $\beta$-galactosidase, $\alpha$-glucosidase, $\beta$-glucuronidase, $\alpha$ mannosidase and $\alpha$-fucosidase activities are absent. Acid is produced from glycerol, ribose, glucose, fructose, $\mathrm{N}$ acetylglucosamine, aesculin, maltose, D-tagatose, starch, xylitol, sucrose and trehalose but not from galactose, melibiose, mannose, turanose, 5-ketogluconate, D- or Larabinose, D- or L-xylose, methyl $\beta$-D-xylopyranoside, rhamnose, methyl $\alpha$-D-mannopyranoside, methyl $\alpha$-Dglucopyranoside, amygdalin, arbutin, salicin, cellobiose, lactose, melezitose, inulin, raffinose, gentiobiose, D- or Lfucose, erythritol, adonitol, sorbose, dulcitol, inositol, mannitol, sorbitol, glycogen, D- or L-arabitol, gluconate and 2-ketogluconate. Major cellular fatty acids include iso$\mathrm{C}_{15: 0} 2-\mathrm{OH}$ and iso- $\mathrm{C}_{16: 0}$. The DNA G+C content of the type strain is $48.1 \mathrm{~mol} \%$. The type strain contains three major polar lipids, phosphatidylglycerol, diphosphatidylglycerol and an unidentified glycolipid.

The type strain, S1-66 ${ }^{\mathrm{T}} \quad\left(=\mathrm{NBRC} 107741^{\mathrm{T}}=\mathrm{KCTC}\right.$ $\left.23434^{\mathrm{T}}\right)$, was isolated from seawater of the western North Pacific Ocean near Japan. 


\section{Acknowledgements}

We are grateful to the captain and crew of R/V Mirai [Japan Agency for Marine-Earth Science and Technology (JAMSTEC)] for their assistance and support in sample collection.

\section{References}

Bae, S. S., Kwon, K. K., Yang, S. H., Lee, H. S., Kim, S. J. \& Lee, J. H. (2007). Flagellimonas eckloniae gen. nov., sp. nov., a mesophilic marine bacterium of the family Flavobacteriaceae, isolated from the rhizosphere of Ecklonia kurome. Int J Syst Evol Microbiol 57, 1050-1054.

Bernardet, J.-F., Segers, P., Vancanneyt, M., Berthe, F., Kersters, K. \& Vandamme, P. (1996). Cutting a Gordian knot: emended classification and description of the genus Flavobacterium, emended description of the family Flavobacteriaceae, and proposal of Flavobacterium hydatis nom. nov. (basonym, Cytophaga aquatilis Strohl \& Tait 1978). Int J Syst Bacteriol 46, 128-148.

Bernardet, J.-F., Nakagawa, Y. \& Holmes, B. (2002). Proposed minimal standards for describing new taxa of the family Flavobacteriaceae and emended description of the family. Int J Syst Evol Microbiol 52, 1049-1070.

Bowman, J. P. \& Nichols, D. S. (2002). Aequorivita gen. nov., a member of the family Flavobacteriaceae isolated from terrestrial and marine Antarctic habitats. Int J Syst Evol Microbiol 52, 1533-1541.

Cho, J. C. \& Giovannoni, S. J. (2003). Croceibacter atlanticus gen. nov., sp. nov., a novel marine bacterium in the family Flavobacteriaceae. Syst Appl Microbiol 26, 76-83.

Choi, T.-H., Lee, H. K., Lee, K. \& Cho, J.-C. (2007). Ulvibacter antarcticus sp. nov., isolated from Antarctic coastal seawater. Int J Syst Evol Microbiol 57, 2922-2925.

Dittmer, J. C. \& Lester, R. L. (1964). A simple, specific spray for the detection of phospholipids on thin-layer chromatograms. J Lipid Res 15, 126-127.

Fautz, E. \& Reichenbach, H. (1980). A simple test for flexirubin-type pigments. FEMS Microbiol Lett 8, 87-91.

Felsenstein, J. (1981). Evolutionary trees from DNA sequences: a maximum likelihood approach. J Mol Evol 17, 368-376.

Felsenstein, J. (1985). Confidence limits on phylogenies: an approach using the bootstrap. Evolution 39, 783-791.

Guindon, S. \& Gascuel, O. (2003). A simple, fast, and accurate algorithm to estimate large phylogenies by maximum likelihood. Syst Biol 52, 696-704.

Khan, S. T., Nakagawa, Y. \& Harayama, S. (2008). Fulvibacter tottoriensis gen. nov., sp. nov., a member of the family Flavobacteriaceae isolated from marine sediment. Int J Syst Evol Microbiol 58, 1670-1674.

Kim, B.-S., Kim, O.-S., Moon, E. Y. \& Chun, J. (2010). Vitellibacter aestuarii sp. nov., isolated from tidal-flat sediment, and an emended description of the genus Vitellibacter. Int J Syst Evol Microbiol 60, 1989-1992.

Kimura, M. (1983). The Neutral Theory of Molecular Evolution. Cambridge: Cambridge University Press.

Komagata, K. \& Suzuki, K. (1987). Lipid and cell-wall analysis in bacterial systematics. Methods Microbiol 19, 161-207.

Lane, D. J. (1991). 16S/23S rRNA sequencing. In Nucleic Acid Techniques in Bacterial Systematics, pp. 115-175. Edited by E. Stackebrandt \& M. Goodfellow. Chichester: Wiley.

Macián, M. C., Pujalte, M. J., Márquez, M. C., Ludwig, W., Ventosa, A., Garay, E. \& Schleifer, K. H. (2002). Gelidibacter mesophilus sp. nov., a novel marine bacterium in the family Flavobacteriaceae. Int J Syst Evol Microbiol 52, 1325-1329.
Marmur, J. (1961). A procedure for the isolation of deoxyribonucleic acid from microorganisms. J Mol Biol 3, 208-218.

Mesbah, M., Premachandran, U. \& Whitman, W. B. (1989). Precise measurement of the $\mathrm{G}+\mathrm{C}$ content of deoxyribonucleic acid by highperformance liquid chromatography. Int J Syst Bacteriol 39, 159-167.

Minnikin, D. E., O’Donnell, A. G., Goodfellow, M., Alderson, G., Athalye, M., Schaal, A. \& Parlett, J. H. (1984). An integrated procedure for the extraction of bacterial isoprenoid quinones and polar lipids. J Microbiol Methods 2, 233-241.

Murray, R. G. E., Doetsch, R. N. \& Robinow, F. (1994). Determinative and cytological light microscopy. In Methods for General and Molecular Bacteriology, pp. 21-41. Edited by P. Gerhardt, R. G. E. Murray, W. A. Wood \& N. R. Krieg. Washington, DC: American Society for Microbiology.

Nedashkovskaya, O. I., Suzuki, M., Vysotskii, M. V. \& Mikhailov, V. V. (2003). Vitellibacter vladivostokensis gen. nov., sp. nov., a new member of the phylum Cytophaga-Flavobacterium-Bacteroides. Int $J$ Syst Evol Microbiol 53, 1281-1286.

Nedashkovskaya, O. I., Kim, S. B., Han, S. K., Rhee, M. S., Lysenko, A. M., Falsen, E., Frolova, G. M., Mikhailov, V. V. \& Bae, K. S. (2004). Ulvibacter litoralis gen. nov., sp. nov., a novel member of the family Flavobacteriaceae isolated from the green alga Ulva fenestrata. Int $J$ Syst Evol Microbiol 54, 119-123.

Nedashkovskaya, O. I., Kim, S. B., Lysenko, A. M., Frolova, G. M., Mikhailov, V. V. \& Bae, K. S. (2005). Bizionia paragorgiae gen. nov., sp. nov., a novel member of the family Flavobacteriaceae isolated from the soft coral Paragorgia arborea. Int J Syst Evol Microbiol 55, 375-378.

Park, S. C., Baik, K. S., Kim, M. S., Kim, S. S., Kim, S. R., Oh, M.-J., Kim, D., Bang, B.-H. \& Seong, C. N. (2009). Aequorivita capsosiphonis sp. nov., isolated from the green alga Capsosiphon fulvescens, and emended description of the genus Aequorivita. Int $J$ Syst Evol Microbiol 59, 724-728.

Reichenbach, H. (1992). The order Cytophagales. In The Prokaryotes, 2nd edn, vol. 4, pp. 3631-3675. Edited by A. Balows, H. G. Trüper, M. Dworkin, W. Harder \& K. H. Schleifer. New York: Springer.

Romanenko, L. A., Uchino, M., Frolova, G. M. \& Mikhailov, V. V. (2007). Marixanthomonas ophiurae gen. nov., sp. nov., a marine bacterium of the family Flavobacteriaceae isolated from a deep-sea brittle star. Int J Syst Evol Microbiol 57, 457-462.

Saitou, N. \& Nei, M. (1987). The neighbor-joining method: a new method for reconstructing phylogenetic trees. Mol Biol Evol 4, 406-425.

Sasser, M. (1990). Identification of bacteria by gas chromatography of cellular fatty acids, MIDI Technical Note 101. Newark, DE: MIDI Inc.

Tamura, K., Dudley, J., Nei, M. \& Kumar, S. (2007). MEGA 4: molecular evolutionary genetics analysis (MEGA) software version 4.0. Mol Biol Evol 24, 1596-1599.

Thompson, J. D., Gibson, T. J., Plewniak, F., Jeanmougin, F. \& Higgins, D. G. (1997). The CLUSTAL_X windows interface: flexible strategies for multiple sequence alignment aided by quality analysis tools. Nucleic Acids Res 25, 4876-4882.

Weisburg, W. G., Barns, S. M., Pelletier, D. A. \& Lane, D. J. (1991). 16S ribosomal DNA amplification for phylogenetic study. J Bacteriol 173, 697-703.

Worliczek, H. L., Kämpfer, P., Rosengarten, R., Tindall, B. J. \& Busse, H. J. (2007). Polar lipid and fatty acid profiles - re-vitalizing old approaches as a modern tool for the classification of mycoplasmas? Syst Appl Microbiol 30, 355-370.

Xie, C. H. \& Yokota, A. (2003). Phylogenetic analyses of Lampropedia hyalina based on the 16S rRNA gene sequence. J Gen Appl Microbiol 49, 345-349. 